\title{
DRIS Evaluation of the Nutritional Status of Crisphead Lettuce
}

\author{
C.A. Sanchez, G.H. Snyder, and H.W. Burdine \\ University of Florida, Institute of Food and Agricultural Sciences, \\ Everglades Research and Education Center, P. O. Box 8003, Belle \\ Glade, FL 33430
}

Additional index words. Lactuca sativa, tissue analysis

\begin{abstract}
Diagnosis and Recommendation Integrated System (DRIS) norms were derived for crisphead lettuce (Lactuca sativa L.) from field fertility experiments conducted over the past 20 years on mineral and organic soils in Florida. Preliminary testing indicates that DRIS diagnoses generally agree with diagnoses using the sufficiency range approach, with the advantage of predicting the degree of nutrient limitation. DRIS also appeared to correctly predict a response to $K$ where sufficiency ranges currently used did not. Overall, DRIS appears to be a useful adjunct to the sufficiency range approach currently used to diagnose nutritional deficiencies in crisphead lettuce.
\end{abstract}

The Diagnosis and Recommendation Integrated System (DRIS) method of interpreting nutrient content of plant tissue has received considerable attention since being detailed by Beaufils (1973). The DRIS approach stresses nutrient balance and provides a means for comparing the degree to which various nutrients limit yield, either as a result of deficiency or excess (Walworth and Sumner, 1987). Because the DRIS approach uses nutrient ratios, it is sometimes less sensitive than the sufficiency range (SR) approach to differences caused by leaf position, tissue age, climate, soil conditions, and cultivar effects. However, a shortcoming of using nutrient ratios is that DRIS may indicate a nutrient limitation for a nutrient that is low relative to others, even though the nutrient may not be limiting yield (Beverly et al., 1984). The incorporation of nutrient concentrations in the DRIS evaluation has been proposed and used as a means of minimizing these erroneous diagnoses (Hallmark et al., 1987; Parent and Granger, 1989).

The DRIS approach has been found to provide reliable diagnosis for agronomic crops (Elwali and Gascho, 1984; Sumner, 1977; Walworth et al., 1986) and for orchard crops (Beverly et al., 1984; Parent and Granger, 1989). However, the possibility of using the DRLS approach for fast-growing short-season leafy vegetables, such as crisphead lettuce, has not been evaluated. The objectives of this work were to derive DRIS norms for crisphead lettuce and perform a preliminary evaluation of the DRIS approach as a tool for diagnosing nutrient deficiencies in lettuce.

The data used for this investigation consisted of 3316 observations from numerous lettuce field fertility experiments conducted between 1971 and 1989 on both mineral and

Received for publication 26 Apr. 1990. Univ. Fla. Expt. Sta. Journal Series no. R-O0624. The cost of publishing this paper was defrayed in part by the payment of page charges. Under postal regulations, this paper therefore must be hereby marked advertisement solely to indicate this fact. of the observations came from experiments conducted on mineral soils, and $80 \%$ of the observations came from experiments conducted on organic soils (Histosols). Details of experimental procedures are presented elsewhere (Sanchez and Burdine, 1988; Sanchez et al., 1988, 1990).

The outermost sound leaf was collected from several plants in each plot in each experiment during the growing season (generally early to midgrowth). The leaves were dried at $60 \mathrm{C}$ and ground for analysis. From 1972 to 1983 , N was determined by steam distillation after micro-Kjeldahl digestion. During this same period, $\mathrm{P}$ was determined calorimetrically, $\mathrm{K}$ and $\mathrm{Na}$ by flame-emission spectroscopy, and $\mathrm{Ca}, \mathrm{Mg}, \mathrm{Fe}, \mathrm{Zn}, \mathrm{Mn}$, and $\mathrm{Cu}$ by atomic absorption spectroscopy, after digestion with $\mathrm{HNO}_{3} / \mathrm{HCIO}_{4}$ acid. During this period, $\mathrm{B}$ was determined using the quinalizarin method (McDougall and Biggs, 1952). In 1984, our laboratory changed to a $\mathrm{H}_{2} \mathrm{O}_{2} / \mathrm{H}_{2} \mathrm{SO}_{4}$ digestion (Wolf, 1982), after which time $\mathrm{N}$ was determined colorimetrically and $\mathrm{B}$ by inductively coupled plasma spectroscopy. Comparisons of digestion methods before the change was made indicated that both methods gave similar results.

Because quality is often the overriding factor determining the market value of lettuce, we used a combined yield-quality index to separate superior and inferior subpopulations rather than yield alone. Lettuce yields were assigned a rating ranging from 1 through 5 for marketable yield levels of $\mathrm{O}$ to 14,15 to 28,29 to 42,43 to 56 , and $>56$ $\mathrm{Mg} \cdot \mathrm{ha}^{-1}$, respectively. The quality of lettuce was rated from 1 to 5 as very poor, poor, fair, good, and excellent, respectively. The lettuce was rated based on head firmness, head size, and the presence of marketing defects, such as tipburn, cracked stems, ribbiness, and rib discoloration (U.S. Dept. Agr., 1973). A yield-quality index was calculated as the multiple of the yield and quality ratings. Marketable yields $>50 \mathrm{Mg} \cdot \mathrm{ha}^{-1}$ are generally only obtainable in the winter-spring (January to March) growing period when the organic soils in southern Florida. About 20\%
Table 1. DRIS norms for lettuce. ${ }^{\mathrm{z}}$

\begin{tabular}{|c|c|c|}
\hline $\begin{array}{l}\text { Nutrient } \\
\text { ratio }\end{array}$ & Mean & SD \\
\hline $\mathrm{N}$ & 3.87 & 0.87 \\
\hline $\mathrm{N}: \mathrm{P}$ & 9.06 & 3.04 \\
\hline $\mathrm{N}: \mathrm{Mg}$ & 8.18 & 3.18 \\
\hline $10 \mathrm{~N}: \mathrm{Mn}$ & 1.09 & 0.64 \\
\hline $\mathrm{P}$ & 0.47 & 0.17 \\
\hline $100 \mathrm{P}: \mathrm{K}$ & 5.56 & 2.59 \\
\hline $\mathrm{P}: \mathrm{Mg}$ & 1.00 & 0.49 \\
\hline $\mathrm{P}: \mathrm{Na}$ & 2.86 & 2.36 \\
\hline $1000 \mathrm{P}: \mathrm{Fe}$ & 3.42 & 2.01 \\
\hline $1000 \mathrm{P}: \mathrm{Zn}$ & 9.24 & 3.79 \\
\hline $100 \mathrm{P}: \mathrm{Mn}$ & 1.67 & 1.50 \\
\hline $100 \mathrm{P}: \mathrm{B}$ & 1.39 & 0.83 \\
\hline $\mathrm{K}$ & 9.64 & 3.11 \\
\hline $\mathrm{K}: \mathrm{N}$ & 2.62 & 1.19 \\
\hline $0.1 \mathrm{~K}: \mathrm{Mg}$ & 1.95 & 0.73 \\
\hline $10 \mathrm{~K}: \mathrm{Mn}$ & 2.96 & 2.22 \\
\hline $10 \mathrm{~K}: \mathrm{B}$ & 3.75 & 1.21 \\
\hline $\mathrm{Ca}$ & $1.62 \ldots$ & 0.57 \\
\hline $10 \mathrm{Ca}: \mathrm{N}$ & 4.41 & 2.09 \\
\hline $10 \mathrm{Ca}: \mathrm{K}$ & 1.93 & 1.12 \\
\hline $\mathrm{Ca}: \mathrm{Mg}$ & 3.23 & 1.34 \\
\hline $100 \mathrm{Ca}: \mathrm{Mn}$ & 4.62 & 3.98 \\
\hline $100 \mathrm{Ca}: \mathrm{B}$ & 5.35 & 2.46 \\
\hline $\mathrm{Mg}$ & 0.54 & 0.24 \\
\hline $100 \mathrm{Mg}: \mathrm{Mn}$ & 1.43 & 1.15 \\
\hline $100 \mathrm{Mg}: \mathrm{B}$ & 1.63 & 0.60 \\
\hline $\mathrm{Na}$ & 0.20 & 0.13 \\
\hline $100 \mathrm{Na}: \mathrm{N}$ & 5.45 & 3.85 \\
\hline $100 \mathrm{Na}: \mathrm{K}$ & 1.88 & 1.57 \\
\hline $10 \mathrm{Na}: \mathrm{Ca}$ & 1.64 & 0.95 \\
\hline $10 \mathrm{Na}: \mathrm{Mg}$ & 4.34 & 3.61 \\
\hline $1000 \mathrm{Na}: \mathrm{Fe}$ & 2.21 & 1.56 \\
\hline $1000 \mathrm{Na}: \mathrm{Zn}$ & $4: 55$ & 2.80 \\
\hline $1000 \mathrm{Na}: \mathrm{Mn}$ & 4.62 & 3.76 \\
\hline $1000 \mathrm{Na}: \mathrm{B}$ & 6.53 & 4.46 \\
\hline $\mathrm{Fe}$ & 174.5 & 97.2 \\
\hline $0.1 \mathrm{Fe}: \mathrm{N}$ & 4.62 & 2.88 \\
\hline $0.1 \mathrm{Fe}: \mathrm{K}$ & 2.09 & 1.41 \\
\hline $0.01 \mathrm{Fe}: \mathrm{Ca}$ & 1.18 & 0.70 \\
\hline $0.01 \mathrm{Fe}: \mathrm{Mg}$ & 3.68 & 2.66 \\
\hline $\mathrm{Fe}: \mathrm{Zn}$ & 3.23 & 1.62 \\
\hline $\mathrm{Fe}: \mathrm{Mn}$ & 4.35 & 2.93 \\
\hline $\mathrm{Fe}: \mathrm{B}$ & 5.45 & 4.28 \\
\hline $\mathrm{Zn}$ & 58.2 & 35.8 \\
\hline $0.1 \mathrm{Zn}: \mathrm{N}$ & 1.56 & 1.38 \\
\hline $\mathrm{Zn}: \mathrm{K}$ & 6.80 & 4.06 \\
\hline $0.1 \mathrm{Zn}: \mathrm{Ca}$ & 4.29 & 3.36 \\
\hline $0.01 \mathrm{Zn}: \mathrm{Mg}$ & 1.24 & 0.85 \\
\hline $\mathrm{Zn}: \mathrm{Mn}$ & 1.61 & 1.33 \\
\hline $\mathrm{Zn}: \mathrm{B}$ & 1.97 & 1.83 \\
\hline $\mathrm{Mn}$ & 53.1 & 38.7 \\
\hline $\mathrm{Cu}$ & 9.6 & 5.7 \\
\hline $\mathrm{Cu}: \mathrm{N}$ & -2.55 & 3.27 \\
\hline $0.1 \mathrm{Cu}: \mathrm{P}$ & 1.83 & 1.43 \\
\hline $\mathrm{Cu}: \mathrm{K}$ & 1.04 & 1.13 \\
\hline $\mathrm{Cu}: \mathrm{Ca}$ & 6.60 & 7.19 \\
\hline $0.1 \mathrm{Cu}: \mathrm{Mg}$ & 2.07 & 2.47 \\
\hline $0.1 \mathrm{Cu}: \mathrm{Na}$ & 5.17 & 11.93 \\
\hline $100 \mathrm{Cu}: \mathrm{Fe}$ & 6.41 & 10.33 \\
\hline $10 \mathrm{Cu}: \mathrm{Zn}$ & 1.60 & 1.44 \\
\hline $10 \mathrm{Cu}: \mathrm{Mn}$ & 3.30 & 4.21 \\
\hline $10 \mathrm{Cu}: \mathrm{B}$ & 1.92 & 1.65 \\
\hline $\mathrm{B}$ & 31.3 & 9.6 \\
\hline$B: N$ & 8.48 & 2.97 \\
\hline $10 \mathrm{~B}: \mathrm{Mn}$ & 5.71 & 3.42 \\
\hline
\end{tabular}

${ }^{\mathrm{z}} \mathrm{N}, \mathrm{P}, \mathrm{K}, \mathrm{Ca}$, and $\mathrm{Mg}$ concentrations are in percent dry weight and $\mathrm{Fe}, \mathrm{Zn}, \mathrm{Mn}$, and $\mathrm{Cu}$ concentrations are in milligrams per kilogram dry weight.

weather is cool and irradiance is relatively high. Limiting yields in the range of 40 to $56 \mathrm{Mg} \cdot \mathrm{ha}^{-1}$ are more frequent; hence, a yieldquality index of 16 was used to separate the subpopulations. 
The nutritional data were expressed in all possible ratios and reciprocal ratios. Additionally, actual concentrations of nutrients (i.e., N/dry matter) were included on the basis of recent evidence indicating that their inclusion may reduce the number of erroneous diagnoses of deficiencies. The mean, standard deviation, and variance were calculated for each nutrient concentration and all ratios between nutrient concentrations for both populations. The form of expression $(\mathrm{N}$ : $\mathrm{P}$ vs. $\mathrm{P}: \mathrm{N}$ ) with the greater variance ratio $\left(\mathrm{s}^{2}\right.$ superior/ $\mathrm{s}^{2}$ inferior) was selected (Table 1). Equations used in the calculation of DRIS indices are described in detail elsewhere (Sumner, 1977; Walworth and Sumner,
1987). SRS currently used in southern Florida to diagnose nutrient deficiencies of lettuce (Table 2) were used to compare DRIS to the SR approach. These SRS closely agree with the common ranges found in lettuce leaves, as reported by Geraldson et al. (1973).

The diagnostic accuracy of DRIS and the SR approach was evaluated using two separate factorial experiments conducted in southern Florida. A nutrient was considered deficient by DRIS when its index was more negative than the DM index (Hallmark et al., 1987; Walworth et al., 1986). For brevity, only the progressive diagnosis (treatment 1 and other treatments indicated by SR or DRLS diagnosis) are shown. The first evaluation

Table 2. Sufficiency ranges of nutrients in the outermost sound leaves of lettuce.

\begin{tabular}{|c|c|c|}
\hline Nutrient & $\begin{array}{l}\text { Sufficiency } \\
\text { range }\end{array}$ & Source of data \\
\hline$N(\%)$ & $4.0-5.0$ & Beverly (1984); Slater and Goodall (1956) \\
\hline $\mathrm{P}(\%)$ & $0.35-0.60$ & $\begin{array}{l}\text { Beverly (1984); Grant Lipp and Goodall } \\
\text { (1958a); Sanchez et al. (1988) }\end{array}$ \\
\hline $\mathrm{K}(\%)$ & $4.8-8.0$ & $\begin{array}{l}\text { Beverly (1984); Grant Lipp and Goodall } \\
\text { (1958b); Sanchez et al. (1988) }\end{array}$ \\
\hline $\mathrm{Ca}(\%)$ & $1.2-2.0$ & Ashkar and Ries (1971); Vlamis (1949) \\
\hline $\operatorname{Mg}^{2}(\%)$ & $0.4-0.8$ & Sanchez et al. (1988) \\
\hline $\mathrm{Fe}^{\mathrm{z}}(\mathrm{ppm})$ & $80-200$ & Sanchez et al. (1988) \\
\hline $\mathrm{Zn}(\mathrm{ppm})$ & $30-60$ & Berry (1971); Boawn and Rasmussen (1971) \\
\hline $\mathrm{Mn}(\mathrm{ppm})$ & $25-130$ & Vlamis and Williams (1973) \\
\hline $\mathrm{Cu}(\mathrm{ppm})$ & $5-10$ & Adams et al. (1978); Davis and Beckett (1978) \\
\hline $\mathrm{B}(\mathrm{ppm})$ & $20-60$ & McHarque and Calfee (1933) \\
\hline
\end{tabular}

${ }^{z}$ We did not have and were unable to locate data where $\mathrm{Fe}$ and $\mathrm{Mg}$ concentrations were actually determined on $\mathrm{Fe}$ - and $\mathrm{Mg}$-deficient plants. Therefore, for these nutrients, the ranges represent those commonly found in healthy lettuce leaf tissue.

compared the response of lettuce to $\mathrm{P}$ and $\mathrm{K}$ fertilization (Table 3). Both the DRIS and SR approach correctly diagnosed the significant $(P<0.01)$ linear response to $\mathrm{P}$ and $\mathrm{K}$ fertilizer. The second evaluation compared the response of lettuce to $\mathrm{N}, \mathrm{P}, \mathrm{K}$, and $\mathrm{S}$ (Table 4). In southern Florida, $\mathrm{S}$ is often applied as an acidifying amendment primarily to increase the availability of Mn (Sanchez, 1990). Both the SR and DRIS evaluation of the $\mathrm{N}_{0} \mathrm{P}_{0} \mathrm{~K}_{1} \mathrm{~S}_{0}$ treatment diagnosed a $\mathrm{P}$ and Mn deficiency, indicating the need for the $\mathrm{N}_{0} \mathrm{P}_{1} \mathrm{~K}_{1} \mathrm{~S}_{1}$ treatment. After this addition, both $\mathrm{SR}$ and DRIS indicated a need for additional $\mathrm{P}\left(\mathrm{N}_{0} \mathrm{P}_{2} \mathrm{~K}_{1} \mathrm{~S}_{1}\right.$ treatment), although no response was obtained. This observation suggests that SR and DRIS diagnostic norms for $\mathrm{P}$ may be too high. However, after addition of the second P treatment, DRIS correctly diagnosed a K deficiency; whereas the SR approach did not. It is possible that current $\mathrm{SR}$ values used for $\mathrm{K}$ are too low. Although many investigators have reported $\mathrm{K}$ sufficiency ranges from $3 \%$ to $5 \%$, recent studies have indicated that lettuce produced in Florida may require a $\mathrm{K}$ leaf concentration $>5 \%$ (Beverly, 1984; Sanchez et al., 1988). However, even setting the lower end of the SR at $6 \%$ would not have identified the $\mathrm{K}$ limitation in this study. Nutrient balance may be a major factor influencing the $\mathrm{K}$ nutritional status of lettuce. Furthermore, the $\mathrm{K}$ requirements of lettuce may be confounded by the level of $\mathrm{Na}$ (Costigan and Mead, 1987). While we had the data base to integrate $\mathrm{Na}$ into the DRIS norms, we, unfortunately, did

Table 3. Progressive diagnoses of response of lettuce to $\mathrm{P}$ and $\mathrm{K}$ fertilizer.

\begin{tabular}{|c|c|c|c|c|c|c|c|c|c|c|c|c|c|c|}
\hline \multicolumn{2}{|c|}{ Treatment $^{2}$} & \multirow[b]{2}{*}{ Factor } & \multirow[b]{2}{*}{$\mathrm{N}$} & \multirow[b]{2}{*}{$\mathrm{P}$} & \multirow[b]{2}{*}{$\mathrm{K}$} & \multirow[b]{2}{*}{$\mathrm{Ca}$} & \multirow[b]{2}{*}{$\mathrm{Mg}$} & \multirow[b]{2}{*}{$\mathrm{Fe}$} & \multirow[b]{2}{*}{$\mathrm{Zn}$} & \multirow[b]{2}{*}{$\mathrm{Mn}$} & \multirow[b]{2}{*}{$\mathrm{Cu}$} & \multirow{2}{*}{$\begin{array}{c}\text { Dry } \\
\text { matter }\end{array}$} & \multirow{2}{*}{$\begin{array}{c}\text { Yield } \\
\left(\mathrm{Mg}^{\circ} \mathrm{ha}^{-1}\right)\end{array}$} & \multirow{2}{*}{$\begin{array}{l}\text { Indicated } \\
\text { treatment }\end{array}$} \\
\hline $\mathrm{P}$ & $\mathrm{K}$ & & & & & & & & & & & & & \\
\hline 0 & 0 & $\begin{array}{l}\text { Concentrationy } \\
\text { DRIS index } \\
\text { SR diagnosis }\end{array}$ & $\begin{array}{l}5.00 \\
8 \\
0\end{array}$ & $\begin{array}{l}0.34 \\
-5 \\
L^{x}\end{array}$ & $\begin{array}{c}4.69 \\
-15 \\
L\end{array}$ & $\begin{array}{l}1.88 \\
3 \\
0\end{array}$ & $\begin{array}{l}0.55 \\
4 \\
0\end{array}$ & $\begin{array}{r}152 \\
0 \\
0\end{array}$ & $\begin{array}{r}40 \\
0 \\
0\end{array}$ & $\begin{array}{r}31 \\
0 \\
0\end{array}$ & $\begin{array}{r}12 \\
3 \\
0\end{array}$ & $\begin{array}{c}\cdots \\
2 \\
--\end{array}$ & 27.8 & $\begin{array}{l}\mathrm{P}_{1} \mathrm{~K}_{1} \\
\mathrm{P}_{1} \mathrm{~K}_{1}\end{array}$ \\
\hline 1 & 1 & $\begin{array}{l}\text { Concentration } \\
\text { DRIS index } \\
\text { SR diagnosis }\end{array}$ & $\begin{array}{l}5.08 \\
11 \\
0\end{array}$ & $\begin{array}{l}0.33 \\
-4 \\
\mathrm{~L}\end{array}$ & $\begin{array}{c}4.16 \\
-21 \\
L\end{array}$ & $\begin{array}{l}2.19 \\
8 \\
0\end{array}$ & $\begin{array}{l}0.56 \\
5 \\
0\end{array}$ & $\begin{array}{r}120 \\
0 \\
0\end{array}$ & $\begin{array}{r}47 \\
1 \\
0\end{array}$ & $\begin{array}{r}22 \\
-3 \\
0\end{array}$ & $\begin{array}{r}10 \\
1 \\
0\end{array}$ & $\begin{array}{c}\cdots \\
2 \\
--\end{array}$ & 29.2 & $\begin{array}{l}\mathrm{P}_{2} \mathrm{~K}_{2} \\
\mathrm{P}_{2} \mathrm{~K}_{2}\end{array}$ \\
\hline 2 & 2 & $\begin{array}{l}\text { Concentration } \\
\text { DRIS index } \\
\text { SR diagnosis }\end{array}$ & $\begin{array}{l}4.91 \\
8 \\
0\end{array}$ & $\begin{array}{l}0.35 \\
-3 \\
\mathrm{~L}\end{array}$ & $\begin{array}{c}4.48 \\
-15 \\
L\end{array}$ & $\begin{array}{l}2.06 \\
4 \\
0\end{array}$ & $\begin{array}{l}0.52 \\
4 \\
0\end{array}$ & $\begin{array}{r}118 \\
0 \\
0\end{array}$ & $\begin{array}{r}38 \\
0 \\
0\end{array}$ & $\begin{array}{r}30 \\
0 \\
0\end{array}$ & $\begin{array}{l}9 \\
0 \\
0\end{array}$ & $\begin{array}{c}\cdots \\
2 \\
\cdots\end{array}$ & 38.7 & $\begin{array}{l}\text { More } \mathrm{K} \text { and } \mathrm{P} \\
\text { More } \mathrm{K} \text { and } \mathrm{P}\end{array}$ \\
\hline
\end{tabular}

zTreatments were three $\mathrm{P}$ rates $\left(0,118\right.$, and $\left.236 \mathrm{~kg} \cdot \mathrm{ha}^{-1}\right)$ and three $\mathrm{K}$ rates $\left(0,223\right.$, and $\left.446 \mathrm{~kg} \cdot \mathrm{ha}^{-1}\right)$ applied in factorial combination.

y $, \mathrm{P}, \mathrm{K}, \mathrm{Ca}$, and $\mathrm{Mg}$ concentrations are in percent dry weight and $\mathrm{Fe}, \mathrm{Zn}, \mathrm{Mn}$, and $\mathrm{Cu}$ concentrations are in milligrams per kilogram dry weight.

'Low (L) tissue concentration or 0 , no limitation.

Table 4. Progressive diagnoses of lettuce response to $\mathrm{N}, \mathrm{P}, \mathrm{K}$, and $\mathrm{S}$.

\begin{tabular}{|c|c|c|c|c|c|c|c|c|c|c|c|c|c|}
\hline $\begin{array}{l}\text { Treatment }^{z} \\
\text { N P K S } \\
\end{array}$ & Factor & $\mathrm{N}$ & $\mathrm{P}$ & $\mathrm{K}$ & $\mathrm{Ca}$ & $\mathrm{Mg}$ & $\mathrm{Fe}$ & $\mathrm{Zn}$ & $\mathrm{Mn}$ & $\mathrm{Cu}$ & $\begin{array}{c}\text { Dry } \\
\text { matter }\end{array}$ & $\begin{array}{c}\text { Yield } \\
\left(\mathrm{Mg} \cdot \mathrm{ha}^{-1}\right)\end{array}$ & $\begin{array}{l}\text { Indicated } \\
\text { treatment }\end{array}$ \\
\hline \multirow[t]{3}{*}{0010} & Concentration $^{y}$ & 4.87 & 0.29 & 7.43 & 1.84 & 0.46 & 238 & 50 & 19 & 14 & $\ldots$ & 15.8 & \\
\hline & DRIS index & 7 & -12 & 0 & 3 & 0 & 7 & 0 & -7 & 2 & 0 & & $\mathrm{~N}_{0} \mathrm{P}_{1} \mathrm{~K}_{1} \mathrm{~S}_{1}$ \\
\hline & SR diagnosis & 0 & $\mathrm{~L}^{x}$ & 0 & 0 & 0 & 0 & 0 & $\mathrm{~L}^{\prime}$ & 0 & -.- & & $\mathrm{N}_{0} \mathrm{P}_{1} \mathrm{~K}_{1} \mathrm{~S}_{1}$ \\
\hline \multirow[t]{3}{*}{01111} & Concentration & 4.76 & 0.34 & 7.35 & 2.26 & 0.56 & 188 & 43 & 38 & 14 & -.. & 28.9 & \\
\hline & DRIS index & 3 & -6 & -1 & 4 & 0 & 0 & -1 & 0 & 3 & -2 & & $\mathrm{~N}_{0} \mathrm{P}_{2} \mathrm{~K}_{2} \mathrm{~S}_{1}$ \\
\hline & SR diagnosis & 0 & L & 0 & 0 & 0 & 0 & 0 & 0 & 0 & $\cdots$ & & $\mathrm{N}_{0} \mathrm{P}_{2} \mathrm{~K}_{1} \mathrm{~S}_{1}$ \\
\hline \multirow[t]{3}{*}{0211} & Concentration & 4.68 & 0.37 & 6.67 & 1.78 & 0.47 & 157 & 42 & 38 & 17 & $\ldots$ & 27.6 & \\
\hline & DRIS index & 3 & -3 & -4 & 0 & 0 & 0 & -2 & 0 & 7 & -1 & & $\mathrm{~N}_{0} \mathrm{P}_{2} \mathrm{~K}_{2} \mathrm{~S}_{1}$ \\
\hline & SR diagnosis & 0 & 0 & 0 & 0 & 0 & 0 & 0 & 0 & 0 & $\cdots$ & & None \\
\hline \multirow{3}{*}{0221} & Concentration & 4.85 & 0.42 & 7.57 & 1.89 & 0.48 & 190 & 51 & 29 & 14 & $\ldots$ & 35.6 & \\
\hline & DRIS index & 1 & 0 & -1 & 0 & 0 & 0 & 0 & 0 & 1 & -1 & & None \\
\hline & SR diagnosis & 0 & 0 & 0 & 0 & 0 & 0 & 0 & 0 & 0 & 0 & & None \\
\hline
\end{tabular}

Treatments were three $\mathrm{N}$ rates $\left(0,34\right.$, and $\left.68 \mathrm{~kg} \cdot \mathrm{ha}^{-1}\right)$, three $\mathrm{P}$ rates $\left(0,74\right.$, and $\left.279 \mathrm{~kg} \cdot \mathrm{ha}{ }^{-1}\right)$, three $\mathrm{K}$ rates $\left(84,181\right.$, and $\left.279 \mathrm{~kg} \cdot \mathrm{ha}^{-1}\right)$, and two $\mathrm{S}$ rates $\left(0\right.$ and $\left.2240 \mathrm{~kg} \cdot \mathrm{ha}^{-1}\right)$ applied in factorial combination.

${ }_{\mathrm{N}}, \mathrm{P}, \mathrm{K}, \mathrm{Ca}$, and $\mathrm{Mg}$ are in units of percent dry weight and $\mathrm{Fe}, \mathrm{Zn}, \mathrm{Mn}$, and $\mathrm{Cu}$ are in units of milligrams per kilogram dry weight.

${ }^{*}$ Low (L) tissue concentration or 0 , no limitation. 
not have data to evaluate the relationship between $\mathrm{K}$ and $\mathrm{Na}$ in the nutrition of lettuce.

Overall, these evaluations indicate that DRIS is a useful tool in diagnosing the nutritional status of lettuce. Additional testing of these norms across various plant growth stages, in lettuce-producing areas outside Florida, and for other nutrient responses in Florida is needed.

\section{Literature Cited}

Adams, P., C.J. Graves, and G.W. Winsor. 1978 Effects of copper deficiency and liming on the yield and copper status of tomatoes, lettuce, and cucumbers in peat. Scientia Hort. 9:199-205.

Ashkar, S.A. and S.K. Ries. 1971. Lettuce tipburn as related to imbalance and nitrogen composition. J. Amer. Soc. Hort. Sci. 96:448-452.

Beaufils, E.R. 1973. Diagnosis and recommendation integrated system (DRIS). Soil Sci. Bul. 1. Univ. of Natal, Pietermaritzburg, South Africa.

Berry, W.L. 1971. Nutrient status of zinc in lettuce evaluated by plant analysis. J. Amer. Soc. Hort. Sci. 96:412-414.

Beverly, R.B. 1984. Nutritional survey of the Everglades vegetable industry. Proc. Fla. State Hort. Soc. 97:201-205

Beverly, R. B., J.C. Stark, J.C. Ojala, and T.W. Embleton. 1984. Nutrient diagnosis of 'Valencia' oranges by DRIS. J. Amer. Soc. Hort. Sci. 109:649-654.

Boawn, L.C. and P.E. Rasmussen. 1971. Crop response to zinc fertilization of alkaline soils. Agron. J. 63:874-876.

Costigan, P.A. and G.P. Mead. 1987. The requirements of cabbage and lettuce seedlings for potassium in the presence and absence of sodium. J. Plant Nutr. 10:385401.

Davis, R.D. and P.H.T. Beckett. 1978. Critical concentrations of copper in lettuce. New Phytologist 80:23-32.

Elwali, A.M.O. and G.J. Gascho. 1984. Soil testing, foliar analysis, and DRLS as guides for sugarcane fertilization. Agron. J. 76:466-470,

Geraldson, C. M., G.R. fGacan, and O.A. Lorenz. 1973. Plant analysis as an aid for fertilizing vegetable crops, p. 365-379. In: L.M. Walsh and J.D. Beaton (eds.). Soil testing and plant analysis. Soil Sci. Soc. Amer., Madison, Wis.

Grant Lipp, A.E. and D.W. Goodall 1958a. Nutrient interactions in lettuce. IV. Phosphorus content and response to phosphorus. Austral. J. Biol. Sci. 11:30-44.

Grant Lipp, A.E. and D.W. Goodall. 1958b. Nutrient interactions in lettuce. V. Potassium content and response to potassium. Austral. J. Biol. Sci. 11:470-483.

Hallmark, W. B., J.L. Walworth, M.E. Sumner, C.J. deMooy, J. Pesek, and K.P. Shao. 1987. Separating limiting from non-limiting nutrients. J. Plant Nutr. 109:1381-1390.

MacDougall, M.M. and D.A. Biggs. 1952. Estimation of boron in plant tissue by the quinalizarin method. Anal. Chem. 24:566-569.

McHarque, J.S. and R.K. Calfee. 1933. Further evidence that boron is essential for the growth of lettuce. Plant Physiol. 8:305-313.

Parent, L.E. and R.L. Granger. 1989. Derivation of DRIS norms from a high density apple orchard established in Quebec Appalachian mountains. J. Amer. Soc. Hort. Sci. 114:915919.

Sanchez, C.A. 1990. Soil testing and fertilizer recommendations for crop production on Histosols in Florida. Univ. Florida (Tech.) Bul. 876.

Sanchez, C.A. and H.W. Burdine. 1988. Rela- tionship between soil test $\mathrm{P}$ and $\mathrm{K}$ levels and lettuce yield on Everglades Histosols. Soil Crop Sci. Soc. Fla. Proc. 47:52-55.

Sanchez, C.A., H.W. Burdine, V.L. Guzman, and C.B. Hall. 1988. Yield, quality, and leaf nutrient composition of crisphead lettuce as affected by N, P, and K on Histosols. Proc. Fla. State Hort. Soc. 101:346-350.

Sanchez, C. A., S. Swanson, and P.S. Porter. 1990. Banding P to improve fertilizer use efficiency of lettuce. J. Amer. Soc. Hort. Sci. 115:581584

Slater, W.G. and D.W. Goodall. 1956. Nutrient interactions in lettuce. III. Nitrogen content and response to nitrogen. Austral. J. Biol. Sci. 10:253-278.

Sumner, M.E. 1977. Use of DRIS for foliar diagnosis of crops at high yield levels. Commun. Soil Sci. Plant Anal. 8:251-268.

U.S. Department of Agriculture. 1973. Standards for grades of lettuce. Agr. Marketing Serv., Washington D.C.

Vlamis, J.1949. Growth of lettuce and barley as influenced by degree of calcium saturation of soil. Soil Sci. 67:453-466.

Vlamis, J. and D.E. Williams. 1973. Manganese toxicity and marginal chlorosis of lettuce. Plant Soil 39:245-251.

Walworth, J.L. and M.E. Sumner. 1987. The diagnosis and recommendation integrated system (DRIS). Adv. Soil Sci. 6:149-188.

Walworth, J. L., M.E. Sumner, R.A. Isaac, and C.O. Plank. 1986. Preliminary DRIS norms for alfalfa in the southeastern United States and a comparison with Midwestern norms. Agron. J. 78:1046-1052.

Wolf, B. 1982. A comprehensive system of leaf analysis and its use for diagnosing crop nutrient status. Commun. Soil Sci. Plant Anal. 13:10351059. 